\title{
EDUCACIÓN
}

\section{Educación paraguaya en el marco de la Constitución Nacional de 1870}

\author{
Celso Obdulio Mora Rojas ${ }^{1}$
}

\begin{abstract}
Resumen
Introducción: La investigación describe el punto en que las disposiciones legales vigentes en el marco de la Constitución Nacional de 1870 han podido asumir la realidad nacional del momento histórico así como el punto en que las disposiciones legislativas han podido interpretar los intereses políticos sociales y económicos de la postguerra del 70 en cuanto a educación.
\end{abstract}

Objetivo: Describir alcance de la Constitución Nacional de 1870 y de las disposiciones emanadas, para interpretar la realidad nacional en cuanto a educación en la postguerra de 1870.

Material y Método: Diseño de investigación cualitativa, mediante compilación, revisión bibliográfica y análisis de información con rigor científico.

Resultados: La Constitución de 1870 consagró algunos articulados apoyando la educación, en los cuales se expresan la libertad de derecho a circulación e introducción de artículos concernientes a educación e instrucción pública; así como obligatoriedad de la educación primaria y de atención preferente del Gobierno, libertad de publicar ideas por la prensa sin censura, derecho de aprender y el empleo de todos los medios posibles para el progreso e ilustración general universitaria.

De 1870 hasta 1890 el interés político primó sobre lo pedagógico. La creación de escuelas era de primera necesidad. En 1872 se creó un Consejo de Instrucción Pública. Por ley de agosto de 1872, se autorizaba al Poder Ejecutivo, contratación de profesores extranjeros para la instrucción pública.

La existencia de escuelas particulares fue una decisión política, en su mayoría sin controles ni supervisiones, pero contribuyendo al mayor alcance de la enseñanza.

La Ley promulgada en 1877 obligaba a los padres a la instrucción en las primeras letras de los hijos.

Entre 1870 y 1890 la educación se orientó más por criterios políticos que pedagógicos, Paraguay no estaba en condiciones de pensar en el cómo y qué enseñar. En los últimos años del siglo XIX el interés de las autoridades pasó de

1. Universidad Nacional de Asunción. Facultad de Ciencias Químicas.

Monografía presentada en el Seminario Aspectos jurídicos, historiográficos y políticos de la educación paraguaya. Doctorado en Educación. UNIBE, Asunción, Paraguay, Agosto de 2018.

E-mail: cmoraroj@gmail.com

DOI: $10.26885 /$ rcei.foro.2018.42 


\section{Educación paraguaya en el marco de la Constitución Nacional de 1870. Mora Rojas}

la escuela primaria a la Escuela Normal.

En Educación Secundaria, el 4 de enero de 1877, el Poder Ejecutivo promulgaba la Ley de fundación del Colegio Nacional. El Colegio Nacional de la Capital tenía un plan de estudios redactado por extranjeros. Posteriormente se crearon otros Colegios.

Una Ley de 1882 creaba la Escuela de Derecho. Fue hito histórico la creación de la Universidad Nacional de Asunción, por Ley promulgada en setiembre de 1889, con tres facultades: Derecho, Medicina y Matemáticas.

La Constitución de 1870 y disposiciones legales, trataron de levantar al Paraguay en la postguerra; con influencia de docentes y textos extranjeros, y concepción de la escuela paraguaya como continuidad de la argentina; la prohibición de hablar Guaraní, creando estereotipos y cierta desnacionalización.

Conclusiones: La educación paraguaya de la postguerra evidenciaba derechos para la instrucción primaria y obligaciones como el deber de los padres de enviar a sus hijos para la instrucción primaria. Se observó influencia de la escuela argentina. No primó la ideología de desnacionalización paraguaya y el Guaraní no desapareció, contribuyó a la existencia del Paraguay Independiente, Libre y Soberano.

Palabras clave: constitución nacional, educación, postguerra.

\section{RefERencias}

Benítez, L. (1981). Historia de la Educación Paraguaya. Asunción, Paraguay. Industrial Gráfica Comuneros.

Chavez, J. (1988). Compendio De Historia Paraguaya. Asunción, Paraguay. LITOCOLOR.

Florentín, F. (2009). Historia de la Educación en el Paraguay de Postguerra 1870 a 1920. Asunción, Paraguay. El Lector.

Pangrazio, M. (2010). Las Constituciones del Paraguay. Asunción, Paraguay. Intercontinental Editora.

Silvera, C. (2011). La Historiografía Paraguaya. Los textos escolares de historia. Experiencia vivida en la posguerra de 1870. Diálogos. Revista do Departamento de História e do Programa de Pós-Graduacao em História, 65-82. 